\title{
USQ: An E-university For An E-world
}

\author{
James Taylor \\ University of Southern Queensland \\ Peter Swannell \\ University of Southern Queensland
}

\begin{abstract}
The rapid rate of technological change and the rapidly growing number of institutions now embarking on Internet-based delivery means that more institutions are involved in distance education than at any other time in history. As institutions throughout the world increasingly offer courses via the Internet, there will emerge a global higher education economy in which institutions will face global competition for students, especially those involved in continuing professional education and lifelong learning. The emergence of the global higher education economy could well act as a catalyst for overcoming the institutional inertia that typifies the organisational culture of many universities. This transition from the Industrial to the Information Age was encapsulated by Dolence and Norris (1995), who argued that to survive organisations would need to change from rigid, formula driven entities to organisations that were "fast, flexible, and fluid" (p. 31) - adjectives not typically used to describe the salient features of universities! This case study outlines the response of a well-established dual mode institution, The University of Southern Queensland (USQ), to the "gales of creative destruction" (Schumpeter, 1950, p. 84) that currently beset higher education institutions throughout the world.
\end{abstract}

\section{Technological Development and Globalisatio}

Distance education operations have evolved through the following four generations (Taylor, 1995): first, the Correspondence Model based on print technology; second, the Multimedia Model based on print, audio and video technologies; third, the Telelearning Model, based on applications of telecommunications technologies to provide opportunities for synchronous communication; and fourth, the Flexible Learning Model based on online delivery via the Internet (Table 1).

While the first generation has a long history, it is generally accepted that most of the technology enhanced distance learning developments have occurred over the past twenty-five years. Indeed, it is fair to say that the fourth generation of distance education is only just beginning to have an impact in many contexts, due partly to the rate of institutional development in higher education, 
which tends to be stymied by a predominantly conservative ethos and associated mindsets.

Until recently, many on-campus educators have largely ignored the new technologies, with the process of face-to-face conventional teaching regarded as patently superior to all other forms of teaching. While distance educators have striven to overcome the tyranny of distance, the perceived constraints associated with limited opportunities for face-to-face interaction, on-campus educators appear to be basically satisfied with traditional approaches. It is in this context of institutional inertia that the senior managers and leaders of educational institutions have been bedevilled by complex decision making structures. The typical collegiate decision making process often entails a sequence of deliberation, documentation, reflection, review and refinement through consideration by a series of learned groups often including a working party, at least one committee, several faculty boards, the Academic Board, the Vice-Chancellor's Executive Committee and perhaps the University Council. This modus operandi for management is no longer sustainable in an environment where the changing scale and scope of technological change is greater than ever. Today, change is the only constant.

As more and more institutions embrace Internet-based delivery (see [http: //www.dlcoursefinder.com] for examples of courses and providers) competition for students is becoming increasingly competitive on a global scale. In effect, a global lifelong learning economy is emerging. The result is that higher education will become increasingly market driven, such that in the near future institutional success will depend primarily on students' perceptions of flexibility of access, quality of service and value for money. Each institution has unique characteristics and will, of course, respond to these challenges in its own way. The individual response of any institution will be a function of its history, present organisational culture and the beliefs and personalities of current institutional leaders. The following exemplary case study of the University of Southern Queensland (USQ) highlights the need for institutional leaders to take a proactive stance and to generate an organisational development strategy appropriate to the ethos of their particular institution.

\section{USQ: Structures, Culture and Processes}

Established by the Australian Federal Government in 1967, to provide oncampus higher education opportunities primarily for residents of the Darling Downs region of Southern Queensland, The University of Southern Queensland (USQ) became a dual mode institution when it initiated distance education delivery in 1977. Twenty-three years later, the USQ has over 13,000 distance education students studying off-campus in over 60 countries, and over 5,000 students studying on-campus in Toowoomba.

International Review of Research in Open and Distance Learning 


\section{Organisational Structure}

An overview of the organisational structure of the University is presented in Figure 1.

\section{Student Profile}

The successful transition to dual mode operations is evident in the current overview of the geographical location of USQ's Australian students (Table 2) and USQ's international students offshore (Table 3).

USQ has more international students studying offshore than any other Australian university. Further, international students studying on-campus constitute more than $20 \%$ of enrolments.

The current ratio of off-campus to on-campus students expressed as a percentage (74\%: $26 \%)$ is a manifestation of USQ's vision "to be a leader in distance and international education" (USQ, 1999). The emphasis on distance education has had a significant impact on the student profile, with a much smaller percentage of school leavers and a larger group of mature age students (Table 4) exemplifying the trend towards lifelong learning.

\section{Academic Programs/Enrolments/Online Access}

The initial transition to dual mode status in 1977 was stimulated by a move to provide professional upgrading opportunities for teachers. However, the rel-

atively rapid transition to dual mode is now reflected by the fact that all six Faculties are involved in the offering of 130 degree programs via the distance education mode. Further, 31 of these programs are now available online [http://www.usqonline.com.au]. Further, all students have online access to a range of services including discussion groups, library services, supplementary instructional resources incorporating links to relevant sites and a variety of student administration functions, including access to personal records of enrolment and academic results. In effect, all 18,000+ USQ students (whether on- or offcampus) have access to a range of online services, whereas approximately 2,000 of these choose to study solely online. When the USQOnline initiative on the NextEd platform was launched in Semester 2 (1999), there was a total of 398 students operating solely online, and 40 of these were new students. In the following four semesters, USQOnline attracted new students according to the following pattern, increasing from 40 to 69 , then to 167 , then to 293 , and finally to 285. The latter number for Semester 3 (2000) entails study from November to February, a semester that is never as popular as the "mainstream" semesters. To date, the highest number of students operating solely online was 2,263 in

International Review of Research in Open and Distance Learning 
Semester 1 (2000). Further, almost without exception the response of these students to the e-learning experience has been universally positive.

\section{Organisational Development: Towards An e-University}

Since embarking on dual mode operations in 1977, the resource allocation model at USQ has enabled the Distance Education Centre (DEC) to emerge as a major cost centre, currently receiving more funding than all but one of the six faculties. An overview of the DEC infrastructure is provided in Figure 2.

Although a detailed description of the role of the various DEC sections is beyond the scope of the present paper (for more detail, see Taylor, 1997), the essence of the USQ approach is encapsulated in the overview of the multi-disciplinary team model to courseware design and development presented in Figure 3.

In the initial phase of the multi-disciplinary unit team process, the content specialists work with an instructional designer on the development of an instructional blueprint for the courseware. This process leads to the development of a sample courseware module at which time access to the relevant technical specialists (graphic designers, audio/video producers, etc.) in the team is available as required. Upon completion of the sample module, the pedagogical approach is reviewed and possibly revised. The refined sample module then acts as a model for the development of the remaining courseware. While this process is systematic and leads to an efficient use of time and resources, it accommodates a wide range of pedagogical approaches appropriate to different disciplines and various student target audiences. The systemic management of the courseware design, development, production and distribution of the courseware has been incorporated into a quality assurance initiative.

In 1997, under the auspices of the International Standards Organisation, the DEC achieved ISO 9001 quality accreditation for the following processes:

- Courseware design and development

- Project management

- Audio and video production

- Photographic services

- Distance learning evaluation

- Examinations preparation and production

- Telecommunications support

- Microcomputer support

International Review of Research in Open and Distance Learning 
- Systems administration

- Courseware production and distribution

- Multimedia development

- Graphics design

- Instructional design research

- Electronic publishing

- Student support systems

- Technical consultation, installation and repairs

- Network design and maintenance

- Organisational management

The allocation of time and resources to achieve ISO 9001 accreditation is symptomatic of the need for USQ, a relatively small, relatively new, regional university, to differentiate itself from the competition emerging in the global higher education economy, which threatens USQ's distance education market. It was also stimulated by an emerging trend whereby an increasing number of business organizations and government departments require ISO accreditation as a prereq-

uisite to any business partnership. Further, the achievement and maintenance of ISO accreditation reflects USQ's commitment to continuous improvement and organisational development as a corporate management strategy. Fortunately, its size, ethos and history mean that USQ does not face some of the potentially insurmountable challenges to change of some of the long established traditional universities. Nevertheless, the effective integration and management of online delivery is the greatest organisational development challenge facing USQ.

\section{Critical Initiative}

The initial impetus for the move to online delivery occurred in 1995 when USQ was the only Australian university to be awarded an AT\&T Global Learning Initiative research grant (U.S. \$50,000). This research grant funded the development of the online delivery of the University's Graduate Certificate in Open and Distance Learning, the first complete program to be offered totally online by an Australian university. In 1996, the quality of the program was recognised by a major review (independently commissioned by IDP Education Australia) of Technology in International Education, which cited the USQ Graduate Certificate in Open and Distance Learning as, "state-of-the-art in international delivery, curriculum content and form" (IDP, 1996). Subsequently, it was selected for a showcase of best practice in leading edge educational technologies

International Review of Research in Open and Distance Learning 
at the 13th Commonwealth Conference of Education Ministers in Gaborone, Botswana, 1996. The success of the initial online program, and the gradual expansion of the development of other online programs, including the Master of Professional Accounting, led to a major strategic, organisational development initiative.

In 1997, recognising that the rate of development was being somewhat stymied by lack of resources, the USQ senior management executive team, with University Council approval, opted to change the liquidity ratio of University operations in order to commit $\$ 3,000,000$ to the development of USQOnline [http: //www.usqonline.com.au]. Through the business arm of the University, the USQOnline initiative includes a major investment in a Hong Kong based company, NextEd, that provides a virtual campus service, not only to USQ, but also to other institutions throughout the world. USQ not only became a foundation shareholder of NextEd, but also became a major customer of the company. Such a strategy not only enabled USQ to gain access to more resources, but also to a wider range of technical and business expertise. USQ's relationship with NextEd has attracted considerable media attention. For example, a major article appeared recently in Forbes Global (Johnstone, 2000). This effective outsourcing of USQ's international virtual campus services also led to the establishment of a number of management committees (Figure 4), which are based primarily on available expertise rather than on representation of each of the major cost centres.

From an organisational development perspective, the Vice-Chancellor's Committee is responsible for: (a) determining the range of courses to be offered online, (b) the associated decisions on resource allocation and (c) the establishment of the management structure aimed at implementing the USQOnline initiative. The Online Teaching Management Committee (OTMC) is essentially concerned with implementing the online teaching programs and ensuring the appropriate professional development of staff. This is coordinated through a series of Faculty Focus Groups, supported by the Staff and Student Support team. This latter team involves staff from the DEC, the Library, Student Services, the Office of Preparatory and Continuing Studies and Information Technology Services, who were previously involved only in various forms of discrete staff training programs. Further, under the auspices of the OTMC, the Research and Evaluation Focus Group is attempting to coordinate investigations into various aspects of the online teaching/learning environment on an institution-wide basis. Such coordination and integration of previously relatively discrete activities is indicative of the emerging more fluid organisational structure of USQ.

The addition of the online mode of delivery of courses previously offered only oncampus and through "traditional" distance education approaches was managed through the well-established unit team process (Figure 3). In many ways, it was a natural step for USQ based on a team teaching ethos established over the past twenty years. It was, of course, not without its pedagogical and logistical chal- 
lenges, with the standard unit-based team approach being supplemented by a series of pedagogically focussed workshops offered to each discipline group, and a series of hands on training sessions to familiarise staff with the features of the delivery platform. A detailed account of the pedagogical issues arising in the addition of the online mode has been published (Postle \& Sturman, 2000). To date USQ has loaded 169 single units/courses, which gain credit towards 31 of the University's award programs. While there has been healthy debate of numerous issues, including workloads, download times, evaluation, cost-effectiveness, online pedagogy and marketing, to name but a few, practically no one has questioned the University's strategic commitment to the development of a significant e-learning capacity

The Online Systems Management Committee (OSMC) is focussing primarily on the technical interface between the outsourced virtual campus software and USQ's existing management information systems, and the associated review of course regulations. Given course accreditation considerations and the legacy of Government legislation and reporting requirements, this task is far from simple. As well as academic and legislative considerations, the work of the OSMC incorporates the establishment of effective technical interfaces between the outsourced virtual campus platform and existing student record systems, electronic library services and financial systems. The OSMC is essentially working within the existing policy and regulatory structures of the University, but with the ultimate goal of enhancing student choice and flexibility. To date, however, the only major initiative that has emanated from the OSMC is a review of financial issues, including course fees and associated refund policies.

The Online Marketing Management Committee (OMMC) challenged the conventional role of academic staff by involving the teaching staff in decisions about marketing through the establishment of an approach based on product managers. With the guidance of the OMMC, which consisted of marketing specialists from the Faculty of Business, the Director of Marketing and Public Affairs, the Marketing Manager of the International Education Centre, the Corporate Relations Manager, and the Commercial Planning Officer (a new position), product managers nominated by the faculties began working on the creation of business plans for each online program. In this task, they were supported by the Commercial Planning Officer and the USQ Account Manager of our commercial partner.

Decisions emanating from the OMMC and endorsed by VCC have since led to the establishment of the USQOnline Support Centre, aimed at engendering effective and timely responsiveness to enquiries from prospective students and monitoring the efficacy of particular marketing activities. The involvement of staff in the commercial aspects of the online initiative is further reflected in the endorsement of another OMMC proposal to establish an incentive scheme, with $2 \%$ of gross revenue being distributed as follows: $1 \%$ to the teaching team at the unit/course level, and 1\% into a bonus pool for all members of the USQ staff

International Review of Research in Open and Distance Learning 
establishment, irrespective of their specific roles, or even their direct involvement in online activities. Yet another initiative stemming from the activities of the OMMC will provide staff with the opportunity to become part of USQNet [http://www. usqonline.com.au], an international network of marketing representatives, who are compensated financially for the recruitment of new students for USQOnline. Such initiatives are a further indication of the more fluid organizational structure and flexible management processes that are emerging to support USQOnline.

The increasingly fluid and flexible nature of USQ is also reflected in the restructuring in January 2000 of the University's marketing function, followed by the recent (June 2000) replacement of the OMMC with the Marketing and Media Co-ordination Committee. The need for a more co-ordinated corporate approach to marketing was recognised by the OMMC, which generated a proposal (subsequently endorsed by VCC) for the establishment of the new Committee, which includes the dean of each faculty. This new initiative is aimed at promoting a corporate approach to the projection of the USQ brand name. The new marketing management structure reflects the University's growing commitment to the strategic importance of e-learning. Further evidence of such a commitment was the establishment (at the behest of the Vice-Chancellor) of a new executive management position Deputy Vice-Chancellor (Global Learning Services) in June 2000. This new position, which entails oversight of the Distance Education Centre, the Library and Information Technology Services, highlights the growing importance of the need to generate an effective synergy between information, pedagogy and technology in the increasingly competitive environment of global higher education.

The organisational development process is, however, not simply a matter of creating new committees and working groups but entails leadership at all levels, not least from the senior management. In laying the foundation for the USQOnline initiative, the Vice-Chancellor and other senior managers addressed a series of University Assemblies and subsequently, a series of meetings were held with each of the faculties and major cost centres to promote the potential strategic benefits to the University. The Deans of the Faculties and other managers of the major cost centres are supporting developments at faculty board meetings and thereby enabling all staff to be associated with the strategic planning process and ultimately the ownership of USQOnline.

\section{Conclusion}

The USQ approach is unashamedly proactive and based on the belief that the Internet is, in Schumpeter's (1950) terms, a revolution that is generating "gales of creative destruction" (p. 84). Rather than keeping the Internet at arm's length through the development of an attractive Web site, USQ has embraced 
the new technology, and is attempting a fundamental rethinking and rewiring of its structure and infrastructure as it strives to become an e-university for the rapidly emerging e-world. While the USQ approach is clearly a function of the specific institutional characteristics and unique personalities that contribute to the ethos of a particular institution, as an exemplary case study it is primarily significant in highlighting the fact that to effect the qualitative change necessary to accommodate the online teaching-learning process, it is also necessary to generate qualitatively different organisational infrastructures.

In many universities the development of online initiatives are not systemic, but are often random acts of innovation, initiated by risk-taking individuals. In contrast, the implementation of web-based applications at USQ is strategically planned, systematically integrated and institutionally comprehensive. This organisational culture evolved over many years, and is essentially a reflection of one of USQ's guiding objectives: "To be a leader in flexible learning and the use of communication and information technologies in a tertiary education context" (USQ, 1999). Recognition of USQ's achievements in these endeavours occurred recently at a presentation made by the Prime Minister of the Good Universities Guides Award of Australia's University of the Year 2000-2001 for criteria focussed on developing the e-University.

The USQ case study demonstrates that technology alone is not sufficient to engender much needed organisational development. The opportunity for institutional leaders is to adopt a proactive stance, and to generate an organisational development strategy appropriate to the ethos of their particular institution, which will lead to the new technologies becoming a structurally integrated part of practically every aspect of institutional operations. If the power of the increasing array of new technologies is to be exploited in higher education, an appropriate organisational development strategy needs to de devised and implemented to bring about necessary institutional reconstruction. Such reconstruction is difficult; learning to use new technology effectively is difficult; both take time and considerable human and physical resources; both demand sustained human intervention. Therein lies the challenge to the leaders and managers of higher education institutions who are serious about playing a significant role in the global higher education economy of the 21st century.

International Review of Research in Open and Distance Learning 


\section{References}

Dolence, M. G. \& Norris, D. M. (1995). Transforming higher education: A vision for learning in the 21st century. Ann Arbor, MI: Society for College and University Planning (SCUP).

IDP Education Australia (1996). Technology in international education. (Research Paper). Canberra, Australia: IDP Education Australia.

Johnstone, B. (2000). Ivory servers. Forbes Global, 3(25), 138-141.

Postle, G. D \& Sturman, A. (2000, June). Models of online learning as a factor in online education: An Australian case study. Keynote address presented at the Society for Research in Higher Education Conference, Stirling, UK.

Schumpeter, J. A. (1950). Capitalism, socialism and democracy (3rd ed.). New York: Harper and Row.

Taylor, J. C. (1995). Distance education technologies: The fourth generation. Australian Journal of Educational Technology, 11(2), 1-7.

Taylor, J. C. (1997). A dual mode model of distance education: The University of Southern Queensland. Open Praxis, 2, 9-13.

USQ (1999). USQ: Who, why, what, how: An overview of USQ's present status and future directions. Retrieved December 21, 2000: [http://www.usq. edu.au/StudAdmin/STATS/PS/USQ-SD.htm].

Citation Format

Taylor, James C. \& Swannell, Peter (2001) USQ: An E-university For An E-world.

International Review of Research in Open and Distance Learning: 2, 1.

http://www.icaap.org/iuicode?149.2.1.1

International Review of Research in Open and Distance Learning 
Table1: Models of Distance Education - A Conceptual Framework (Below/End)

\begin{tabular}{|c|c|c|c|c|c|}
\hline \multirow{3}{*}{$\begin{array}{l}\text { Models of Distance } \\
\text { Education and } \\
\text { Assodated Delivery } \\
\text { Technologies }\end{array}$} & \multicolumn{5}{|c|}{ Characteristics of Delivery Technologies } \\
\hline & \multicolumn{3}{|c|}{ Flexibiliny } & $\begin{array}{l}\text { Fighly } \\
\text { Refined }\end{array}$ & $\begin{array}{l}\text { Advanced } \\
\text { Interadive }\end{array}$ \\
\hline & Time & Flace & Pace & Materials & Delivery \\
\hline $\begin{array}{l}\text { Frst Generation: } \\
\text { The Correpondence } \\
\text { Model } \\
\text { - Print }\end{array}$ & Yes & Yes & Yes & Yes & No \\
\hline $\begin{array}{l}\text { Second Generation: } \\
\text { The Mfultimetia Model } \\
\text { - Print } \\
\text { - Audiotape } \\
\text { - Videotape } \\
\text { - Computer-based leaming } \\
\text { - (e.g. CML/CAL) } \\
\text { - Irteractive video (disk } \\
\text { sud tape) }\end{array}$ & $\begin{array}{l}\text { Yes } \\
\text { Yes } \\
\text { Yes } \\
\text { Yes } \\
\text { Yes }\end{array}$ & $\begin{array}{l}\text { Yes } \\
\text { Yes } \\
\text { Yes } \\
\text { Yes } \\
\text { Yes }\end{array}$ & $\begin{array}{l}\text { Yes } \\
\text { Yes } \\
\text { Yes } \\
\text { Yes } \\
\text { Yes }\end{array}$ & $\begin{array}{l}\text { Yes } \\
\text { Yes } \\
\text { Yes } \\
\text { Yes } \\
\text { Yes }\end{array}$ & $\begin{array}{l}\text { Ho } \\
\text { Ho } \\
\text { Ho } \\
\text { Yes } \\
\text { Yes }\end{array}$ \\
\hline $\begin{array}{l}\text { Third Generation: } \\
\text { The Teleleaming Model } \\
\text { - Audiotele conferencing } \\
\text { - Video conferencing } \\
\text { - Audiograhic } \\
\text { Commmication } \\
\text { - Broddcast TWRadio and } \\
\text { Audiotele conferencing }\end{array}$ & $\begin{array}{l}\text { No } \\
\text { No } \\
\text { No } \\
\text { No }\end{array}$ & $\begin{array}{l}\text { No } \\
\text { No } \\
\text { No } \\
\text { No }\end{array}$ & $\begin{array}{l}\text { Ho } \\
\text { Ho } \\
\text { Ho } \\
\text { Ho }\end{array}$ & $\begin{array}{l}\text { No } \\
\text { No } \\
\text { Yes } \\
\text { Yes }\end{array}$ & $\begin{array}{l}\text { Yes } \\
\text { Yes } \\
\text { Yes } \\
\text { Yes }\end{array}$ \\
\hline $\begin{array}{l}\text { Fourth Generation: } \\
\text { The Flexible Leaming } \\
\text { Model } \\
\text { - Irter active multimedia } \\
\text { (ThMu) } \\
\text { - Irtemit-based access to } \\
\text { WWW resources } \\
\text { - Computer mediated } \\
\text { commmic ation }\end{array}$ & $\begin{array}{l}\text { Yes } \\
\text { Yes } \\
\text { Yes }\end{array}$ & $\begin{array}{l}\text { Yes } \\
\text { Yes } \\
\text { Yes }\end{array}$ & $\begin{array}{l}\text { Yes } \\
\text { Yes } \\
\text { Yes }\end{array}$ & $\begin{array}{l}\text { Yes } \\
\text { Yes } \\
\text { Ho }\end{array}$ & $\begin{array}{l}\text { Yes } \\
\text { Yes } \\
\text { Yes }\end{array}$ \\
\hline
\end{tabular}


Figure 1: Organisational Structure of USQ (Below/End)

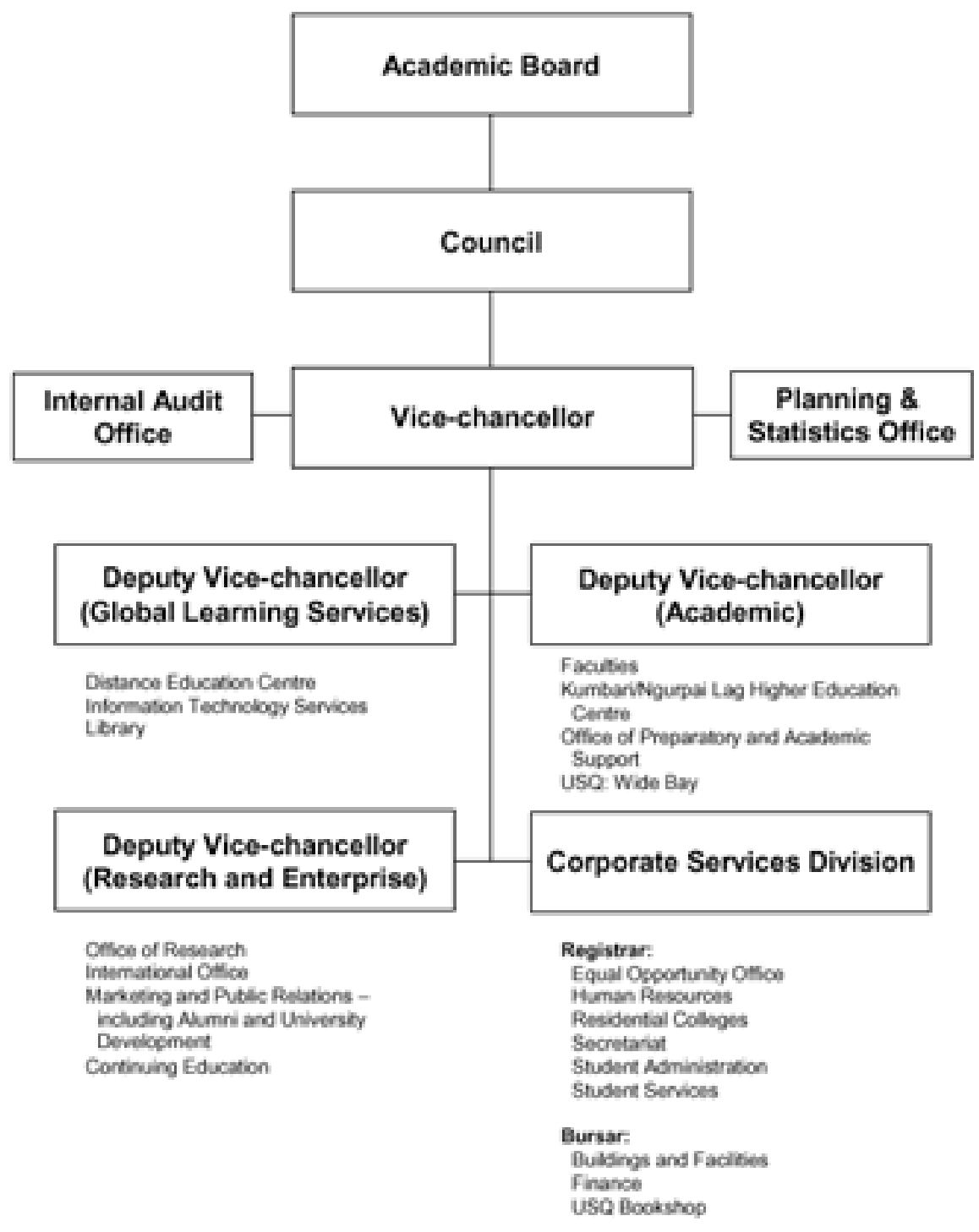

International Review of Research in Open and Distance Learning 
Table 2: Location/Number of USQ's Australian Distance Education Students in 1999 (Below/End)

\begin{tabular}{|c|c|}
\hline Region & 1999 Enrohments \\
\hline Queersland & 7,597 \\
\hline New South Wales and ACT & 1,463 \\
\hline Victoria & 354 \\
\hline South Australia & 174 \\
\hline Western Australia & 156 \\
\hline Northen Tenitory & 100 \\
\hline Tasmania & 79 \\
\hline Australians living overseas & 280 \\
\hline TOTAL & 10,203 \\
\hline
\end{tabular}

Table 3: USQ's International Students Offshore in 1999 (Below/End)

\begin{tabular}{|c|c|}
\hline Region / Country & 1999 Enrohments \\
\hline Malaysia & 1,097 \\
\hline Singspore & 928 \\
\hline Hong Kong & 353 \\
\hline South Africa & 163 \\
\hline Pacific Islands & 100 \\
\hline Other Afric a & 89 \\
\hline Thailand & 88 \\
\hline Other Asia & 68 \\
\hline United Arab Emirates & 46 \\
\hline Other countries & 41 \\
\hline Canada & 32 \\
\hline Japan & 20 \\
\hline United Kingdom & 20 \\
\hline Korea (Nth and Sth) & 20 \\
\hline Pspus New Gunines & 17 \\
\hline Indonesia & 17 \\
\hline Irudia & 17 \\
\hline USA & 15 \\
\hline China & 13 \\
\hline TOTAL & 3,154 \\
\hline
\end{tabular}


Table 4: Nature of USQ's Off-campus Student Population: 1999 (Below/End)

\begin{tabular}{|c|c|c|c|c|}
\hline Variables & $\begin{array}{c}\text { Australian } \\
\text { Based }\end{array}$ & $\begin{array}{c}\text { Temporary } \\
\text { Kisa }\end{array}$ & $\begin{array}{c}\text { Resident } \\
\text { Off-shore }\end{array}$ & TOTAL \\
\hline Age & & & & \\
\hline Under 20 & $3 \%$ & $0 \%$ & $0 \%$ & $3 \%$ \\
\hline $20-24$ & $13 \%$ & $1 \%$ & $7 \%$ & $21 \%$ \\
\hline $25-29$ & $17 \%$ & $0 \%$ & $5 \%$ & $22 \%$ \\
\hline $30-34$ & $14 \%$ & $0 \%$ & $4 \%$ & $18 \%$ \\
\hline $35-39$ & $13 \%$ & $0 \%$ & $3 \%$ & $16 \%$ \\
\hline $40-49$ & $14 \%$ & $0 \%$ & $2 \%$ & $16 \%$ \\
\hline $50-59$ & $3 \%$ & $0 \%$ & $1 \%$ & $4 \%$ \\
\hline Over 59 & $0 \%$ & $0 \%$ & $0 \%$ & $0 \%$ \\
\hline T0TAL & $\mathbf{7 7} \%$ & $\mathbf{1} \%$ & $\mathbf{2 2} \%$ & $\mathbf{1 0 0} \%$ \\
\hline \hline Gende & & & & \\
\hline Female & $38 \%$ & $1 \%$ & $10 \%$ & $49 \%$ \\
\hline Male & $40 \%$ & $1 \%$ & $10 \%$ & $51 \%$ \\
\hline TOTAL & $\mathbf{7 8} \%$ & $2 \%$ & $20 \%$ & $\mathbf{1 0 0} \%$ \\
\hline \hline
\end{tabular}

Figure 2: Staff Establishment of the USQ Distance Education Centre (Below/End)

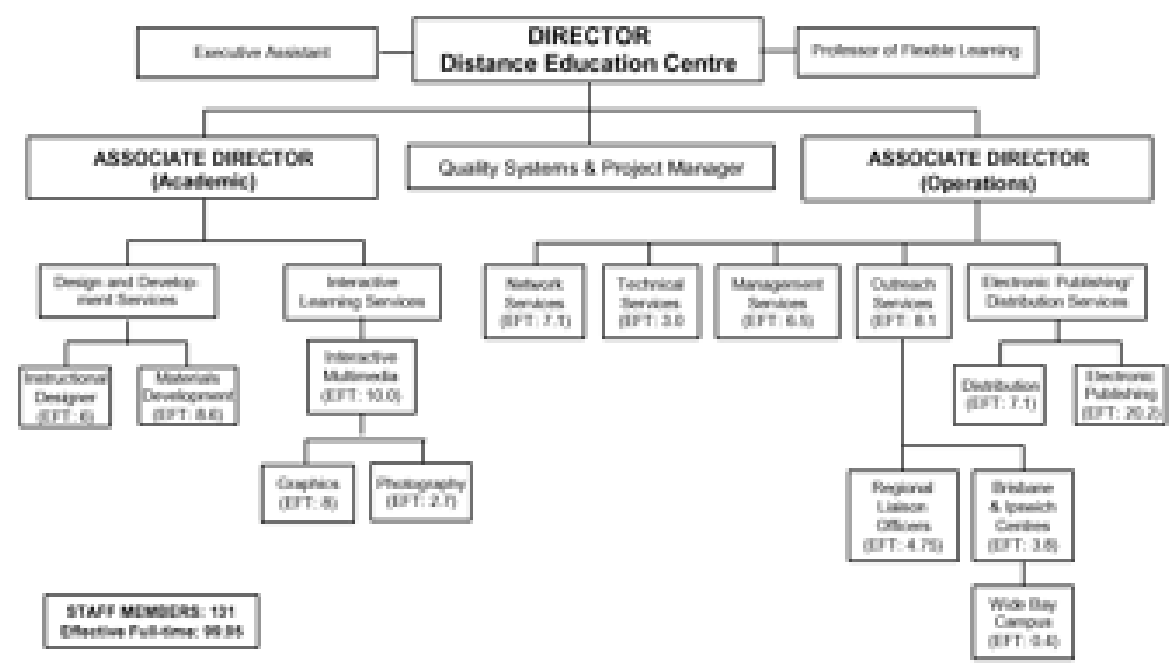

International Review of Research in Open and Distance Learning 
Figure 3: Unit Team Model (Below/End)

The USQ Approach to Courseware Design and Development CONTENT SPECIALISTS

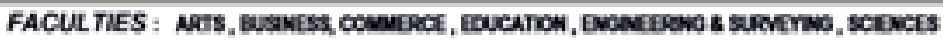

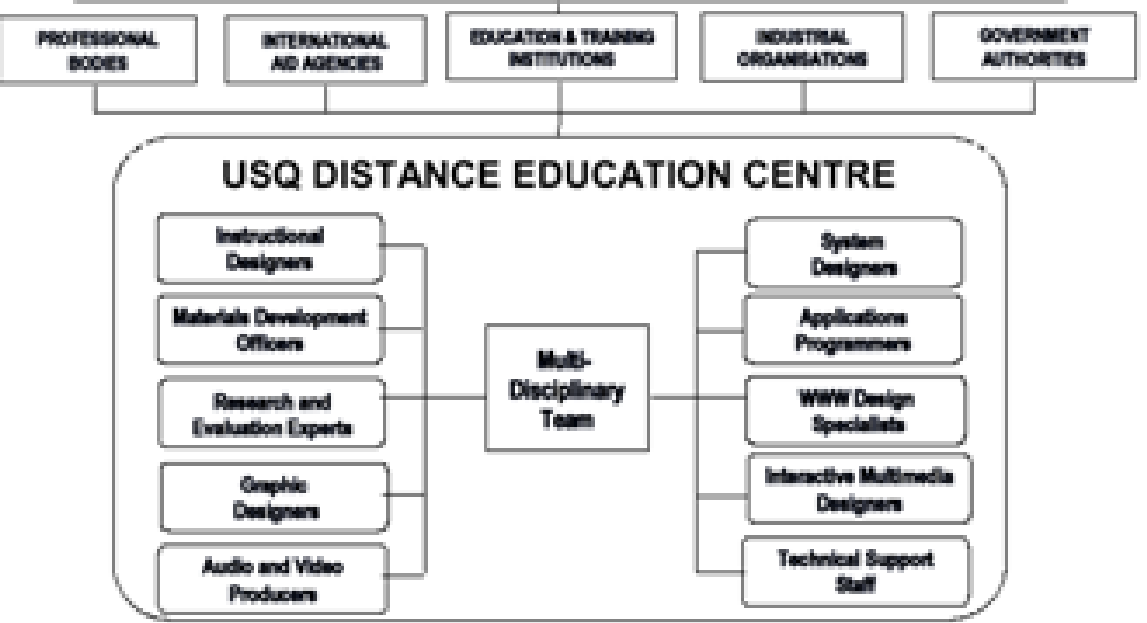

Figure 4: Management Structure of Online Initiatives (Below/End)

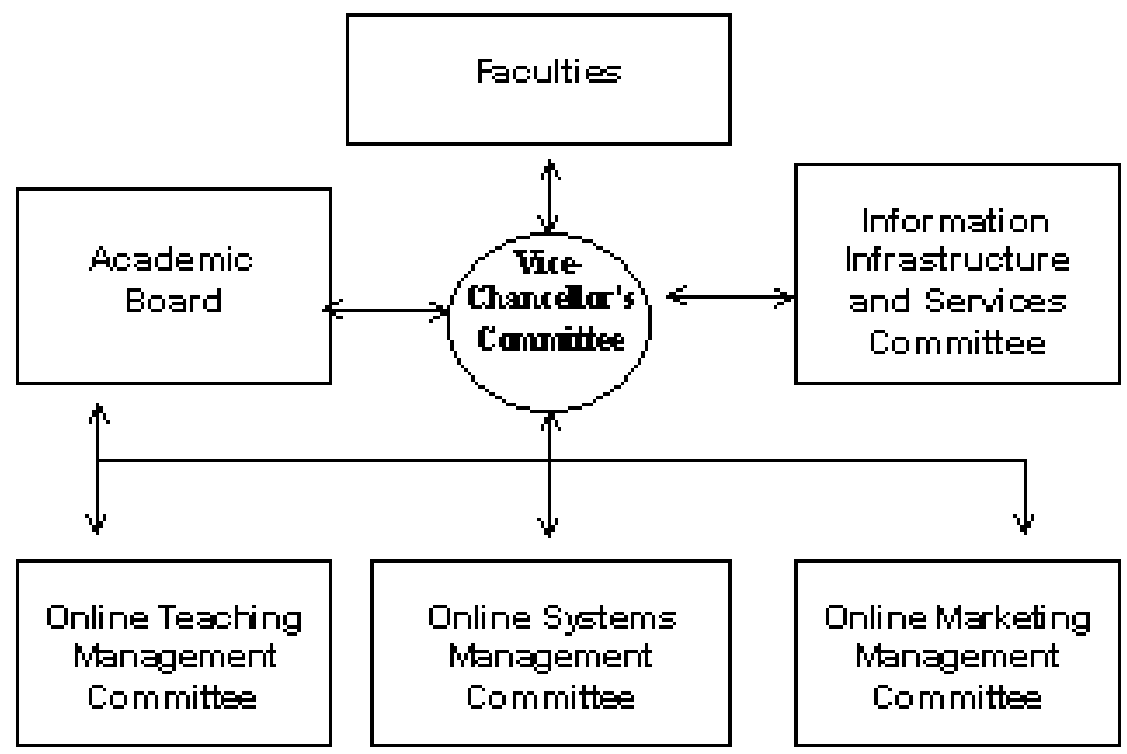

International Review of Research in Open and Distance Learning 